\title{
The culture of modern public administration.
}

\section{The case of Greece.}

\section{Prof. George M. Aspridis}

University of Thessaly, Greece

Hellenic Open University (HOU), Greece

Msc. Louisa Pouliana

Directorate of Secondary Education of Trikala, Greece

\begin{abstract}
The period stretching from 1974 till now has been characterized as the most stable period of the political and administrative history of Greece. However, the appropriate organizational culture which can contribute to the creation of a strategic vision for Greek public administration has not yet been shaped. Therefore, the public sector is not efficient and productive. On the contrary, bureaucratic pathogenies are particularly prevalent. These pathogenies have been rendered even more intense during the economic crisis and the recent pandemic. It is necessary that the modern culture of public administration be focused on effective cooperation, the satisfaction of both citizens and administrative executives' expectations, respect for the individuality and development of public sector executives, the enhancement of public services' good reputation, assessment, communication and finally the implementation of the principles of ethics, integrity and legitimacy. The culture of a modern public administration should be based on the principles of new public management and electronic government. This article is based on the study of secondary sources, more specifically institutional texts, international and national organizations' reports, studies, historical texts, as well as civil servants' views. The conclusions are particularly significant and can spark off the change of the organizational culture in public administration.
\end{abstract}

Keywords: Civil Servant; Electronic Government; New Public Management; Organizational Culture; Public Administration.

\section{Introduction}

Organizations constitute one of the basic characteristics of modern society and civilization. They dominate every possible action taken and it is necessary that we accept their culture in order to function within them. Organizational culture has started being studied as a field of anthropology and especially cultural anthropology since the 1940 s and subsequently, the theorists of Administrative Science tried to study the culture of organizations. Organizational culture can potentially constitute a method of motivating employees, contribute to the increase of efficiency and effectiveness and assist the achievement of the goals set by each organization (Broustas, 2003; Hofstede, 1991). 
G. Hofstede studied the dimensions of national culture and defined them as follows: Process-oriented versus results-oriented, job-oriented versus employee-oriented, professional versus parochial, open system versus closed systems, tight versus loose control and finally pragmatic versus normative (Hofstede, 2011).

The word culture means to tend, to cultivate and refers to the preparation and care of the soil for crops. There are dozens of definitions for the word culture. Thus, the use of only one definition would not ascribe to reality and would change the concept's multilevelity and its various meanings. More specifically, when it comes to organizations, such as ministries, referring to culture has to do with the shaping of the mentality and internal processes within them (Lozga et al, 2018; Broustas, 2003; Gavriil, 1995).

The most well-known definition is attributed to Professor Edgar Schein (2004), who defines that organizational culture is "a pattern of shared basic assumptions that the group learned as it solved its problems of external adaptation and internal integration, that has worked well enough to be considered valid and, therefore, to be taught to new members as the correct way to perceive, think, and feel in relation to those problems" (Koulouri, 2019, p. 6) ${ }^{1}$. According to Schein, organizations do not shape their culture in a day; quite the opposite. A long time period is required, as well as adaptation to the environment and solutions to the problems. They learn from the history and shape their culture resulting in the immediate and stress-free adaptation of the new executives.

In its simplest capture, organizational culture is considered as the essence that keeps the organization united through shared meanings, values and goals, conducive to the content enhancement of organizations and the public sector (Martin et al, 1983).

Regarding the methodology used, the study attempts to answer the following research question: What are the particular characteristics of the Greek public administration culture and how has it evolved? The methodological tool used is critical review of bibliography in combination with cohort study. This method is sufficiently constructive and provides a critical analysis, is based on sampling and specific arguments relevant to the sources studied. The sources available for the critical review of bibliography include primary ones (such as reports, the ethnographic approach and government publications), secondary ones (such as articles, books, narratives and others) and finally tertiary ones (such as databases, indexes and others). In this study, the opinions of authors are cited aiming at shaping the final views and conclusions. The cohort study refers to the observation of the changes in the perceptions of a population over different time periods (Chalikias et al, 2015). This recording represents a first attempt and may constitute the basis for future research projects based on quantitative data to

${ }^{1}$ Koulouri, A. (2019). Organizational culture in health services: Characteristics, advantages and disadvantages. Hellenic Journal of Nursing Science, 12(1), 5-12 (in Greek). 
highlight the improvement of a new and more effective modern public administration culture (Saunders et al, 2014).

\section{The culture of Greek public administration}

The glue that holds an organization together through shared patterns, meanings, values and goals towards content enhancement. (J. Martin - C. Siehl)

In early 2019 during an interview with the Athens-Macedonian News Agency (AMNA), the Greek Ombudsman A. Pottakis (2019) stated that taking into account his first-hand experience since his appointment as the head of the Greek Ombudsman, the culture of the Greek public administration has not changed. More specifically, he said that "while its cost may be smaller, it has not changed in a way visible to ordinary citizens in their daily routine as it should have been, meaning public administration as a service to citizens. Its efficiency has not greatly improved, though the citizens' obligations to it have increased. However, in all fairness, over the last ten years public administration was called upon to change itself many times through a barrage of new laws and provisions and numerous internal redeployments" (Pottakis, 2019)².

Panagiotis Kondylis considers that the beginning for the shaping of the modern state and by extension public administration culture was the result of the imposition of a liberal parliamentary system on a society characterized by conservative principles and deeply affected by the almost-four-century Ottoman rule (Tsekos, 2003). It is typical that the state did not have the possibility to exercise the monopoly of legitimate physical violence and deficiencies occurred in the implementation of the Weberian model. Thus, a hybrid Weberian administrative model was shaped which did not bring about the expected results regarding the establishment and evolution of the administration of the state. The state has constituted the greatest employer in modern history for many and diverse reasons (mostly clientelist) (Kondylis, 2007).

The first Governor I. Kapodistrias wrote that

"it is true that this regime, for which I have already been preparing the Greeks for two years so far, is not clear to them yet (...) because the local mores shaped under the Turkish administration cannot be reformed within two or three years ${ }^{\prime 3}$ (Zeugaridis et al, 1997, p.16).

Professor K. Tsoukalas (1986 and 1987) reports that the integration of a large number of employees in public administration both coming from the lower social classes and being more specialized and better-trained had a significant impact on the shaping of public administration culture. The population of civil servants is smaller in relation to

${ }^{2}$ Pottakis, Andr. (2019). Ombudsman: The culture of public administration has not changed. AMNA Retrieved from https://www. amna.gr/home/article/333090/Sunigoros-tou-Politi-And-Pottakis-Einai-megalo-to-stoichima-gia-na-to-chasoume (in Greek).

${ }^{3}$ Zeugaridis, Sp., \& Stamatiadis G. (1997). Human resources management and supervision. Athens: Interbooks (in Greek). 
the Organization for Economic Co-operation and Development (OECD) countries. Its main characteristics were the sense of omnipotence, narrow-mindedness, the inability of public administration employees to operate on the basis of a set of bureaucratic impersonal rules, as they were formed by Max Weber, that is an organizational structure characterized by rules, standardized procedures and demands, a detailed division of labour and shared responsibility, a hierarchical structure and almost impersonal interactions among its employees (Kondylis, 2007). The afore-mentioned view is supported by other authors as well (National Centre for Public Administration and Local Government - EKDDA, 2012).

Professor N. Diamandouros argues that the culture of the Greek state and its mechanisms is the result of introducing western and liberal policies to a traditionallystructured society affected by both the byzantine and the ottoman heritage, hence creating "the dualism of a reformative and an obsolete culture as well"4 (Mandravelis, 2011, p. 27) (meaning the division of the country between the East and the West).

Professor K. Tsoukalas (1987, p. 39) mentions diverse views on culture shaping and highlights "the adherence of civil servants to national passions and their desire to form their own way of thinking based on the dominant forms of national thought" 5 . Besides, the Greek state was formed in a pre-capitalist traditionally-structured society, where the civic and liberal institutions were introduced by Otto's Bavarians. The state and public administration contributed to the establishment of social relations and constituted the main employer to tackle unemployment and support the upward social mobility of citizens as well. All this resulted in the "swelling" of the state and public services after 1980 (Tsoukalas, 1987). In any case, either before or after the 1980s the Greek state was not larger than the respective European average. However, the state could not utilize the available economic and human resources to achieve its goals (Iordanoglou, 2012).

Professor St. Ladi $(2015$, p. 7$)$ argues that "what can be concluded is that it is not the number of civil servants that puts a strain on the state budget, since it is much smaller than the Eurozone average and is at levels similar to the number of civil servants in most Eurozone member-states. In any case, it cannot be easily argued that the Greek public sector is exceedingly large, since the deviation from the rest Eurozone countries is not so significant either regarding the number of civil servants or the amount of public expenditure" ${ }^{\prime 6}$.

\footnotetext{
${ }^{4}$ Mandravelis, P. (2011, November 6). The No's and Yes' in Greek history. Sunday's Kathimerini, 27 (in Greek).

${ }^{5}$ Tsoukalas, K. (1987). State, society, work in post-war Greece (2nd ed.). Athens: Themelio (in Greek).

${ }^{6}$ Ladi, St. (2015). Is it true that the Greek public sector is too big?. ELIAMEP. Retrieved from https://crisisobs.gr/2015/04/stellaladi-ine-alithia-oti-o-dimosios-tomeas-stin-ellada-ine-ipervolika-megalos/ (in Greek).
} 


\section{Historical influences in the establishment of the organizational culture in public administration}

The organizational culture of public administration has also been shaped by diverse historical circumstances, especially after the end of the Second World War. From the end of the civil war onwards, public administration became accessible to members of working-class and farming families too. In conclusion, K. Tsoukalas agrees that the classic model of bureaucracy could not be implemented in Greek public administration. The shaping of the Greek state and by extension public administration was not established according to the Weberian model. (Tsoukalas, 1987).

The clientelist system has stabilized at executives' level, constitutes part of the broader administrative and political culture and is the functioning way of the modern state (Manager, 2016). This is due to collective interests and their reproduction even within the state entity. For example, as public administration legend has it, I. Kolettis, the $19^{\text {th }}$ century Prime Minister, used to invite citizens to his house, so that he would secure a post for them in the public sector the soonest possible. Later on, more specifically in the late 19th century, buying votes and clientelist relations continued to constitute the main means of citizen mobilization (Vournas, 1998).

The clientelist system constitutes a broader strategy for the political and administrative organization, leading to the creation of a strategic collective action of the stakeholders (Trantidis, 2016). Throughout all these years the culture of ineffectiveness of public administration has prevailed, as it has been recorded in expert reports from the Second World War to this day (Tsekos, 2015; Sotiropoulos, 2001).

According to Professor A. Manitakis, the main problems regarding the shaping of modern organizational structure are overregulation and misgovernment, laws passed on a case-by-case basis, unenforceable laws and finally fear of accountability. In Greek reality, the significance of administrative experience, innovation and technocratic knowledge is not recognized. Instead, the desire for the predominance of political action over administrative action is maintained resulting to the shaping of specific views, attitudes, perceptions and opinions of all stakeholders, and subsequently the existing organizational culture (Manitakis, 2015).

The lack of organizational culture also appears in various aspects of the administrative phenomenon. Typical examples include the absence of assessment culture, the lack of trust in the results of assessment process, as well as the general suspicion lurking in superiors' evaluative judgement of all civil servants (Spanou, 2018). The main characteristics and disfunctions of organizational culture in public administration had to do with the human resources policies, which were based on clientelist relations. Subsequently, organizational development was also based on clientelist relations rather than the real needs of administration. Furthermore, tolerance of irregularity 
was a dominant phenomenon and as a result, citizens themselves are also used to acquiring a particular culture, that of circumventing their formal obligations. Due to clientelist relations, most public policies are judged as ineffective (EKDDA, 2012).

The administrations of Western European states have shaped the culture of the public sector both through specialized structures of employees' education and training, such as the French National School of Administration (ENA). In Western Europe, Civil Society organizations play a significant part in culture shaping, too. Civil servants in Western European countries play a much more significant part in contrast to their Greek colleagues. On the contrary, in Greece frequent government changes result in administrative discontinuity and inability of shaping organizational culture, while senior officials are powerless in relation to the political personnel in administration.

According to Professor K. Spanou (2018, p. 72), there is a call for "change in culture and mentality both at political leaders' level and at executives' level. The former should, on the one hand, accept a restrictive, controlled, coherent framework for financial management over a period of three years, and on the other hand, set priorities responsibly in the context of restricted resources. Even in the case that the restrictive framework may appear at some point to loosen, it is not absolutely certain that selective subversive behaviors at micro level will not be observed, under the radars of fiscal institutions that have been created and the undermining from within of the new fiscal framework. The latter have been credited with the role of guardian, which alters the realities of the administration-policy balance. They are obliged to shoulder management responsibilities without the protection of preventive controls which were ensuring them a risk-free wider margin of maneuver and facilitation in case of intra-ministerial disagreement. They should assume a strategic role setting aside the security of management routine" ${ }^{\prime \prime}$. One of the first services that attempted to change its culture was the General Accounting Office (Spanou, 2018).

\section{Organizational culture, public administration and civil servants}

Civil servants constitute the representatives of the functioning of the state and contribute to the shaping of public administration culture. This culture is shaped by the shared attitudes and behaviors of civil servants, their actions and operations and the overall productivity of public administration (Prevezanou, 2011). A new civil service culture was impossible to be shaped, because in exchange for the clientelist rationale the establishment of a "powerful, professionally-oriented civil service (was prevented)

${ }^{7}$ Spanou, K. (2018). Reforms in Public Administration under the crisis: Overview, Description, Evaluation. Athens: ELIAMEP (in Greek). 
at the expense of a powerful civil society that would have claims from the state" 8 (Prevezanou, 2011, pp. 114-115).

The Civil Servants' Confederation research emphasizes that civil servants realize that new technologies and the digitalization of work form new tasks and a different way of organizing work. Civil servants believe that the changes move towards the improvement of public service functioning and the increase of their efficiency (Gioulos et al, 2019).

Since 1974, the main causes of bureaucratic pathogenies and disfunctions have been large and slow-moving governments, constant changes in the political and administrative organization, changes in the allocation of competences between ministries and services, as well as fragmented administrative structures. Administrative complexity, overregulation, state fragmentation along with the many levels of administration, violation of the institutional obligations on the part of the state and citizens, and finally the "swelling" of the state, which did not necessarily signify the qualitative upgrading of public administration, were attributed to all the stakeholders. In parallel, Greek administration is characterized by the lack of data collection and utilization, yet, such an action would constitute a significant organizational change (Tsivakou, 2013; Makrydemetres et al, 2012; Mouzelis, 2008; Kondylis, 2007).

Furthermore, during the Third Hellenic Republic the transition from the Dictatorship of the Colonels to Democracy played a significant role in the shaping of public administration culture. The administrative mechanism was weak and without any professionalism, based on employees exhibiting limited knowledge and culture after the seven-year dictatorship (Sotiropoulos, 2001). All the previous references are related to the disfunctionality of Greek public administration in matters that have to do with structure and are related to public administration culture, concepts which are interdependent and directly related. The cycle of favouritism, clientelist system and lack of citizen participation continues in the framework of public administration (Tsekos, 2003).

One of the differences between the Greek state and European states is the fact that whatever culture deficiencies the latter may have exhibited, they were balanced by economic efficiency and continuous economic growth. Instead, in Greece dominant were the clientelist relations and inability of shaping an effective public administration characterized by a modern culture. The administrative systems of the EU memberstates are characterized by heterogeneity and differ in terms of the strategies and policies used, due to both the existing different bureaucratic structures and their historical origins (Kondylis, 2007).

${ }^{8}$ Prevezanou, K. (2011). The dimension of the actual and the expected in the behavior and attitudes of civil servants from 1995 to 2005. Athens: Papazisis (in Greek). 
A main difference in the administrative culture between Greece and Western Europe is the lack of a culture of dialogue, argumentation and consultation as a result of Ottoman rule and the overall social development (Manager, 2016). The state's evolution of public administration culture goes hand-in-hand with that of the rest of Europe, yet with a delay in a number of issues and presenting special characteristics due to both national culture and the internal pathogenies of administration despite all the efforts of modernization and the reforms carried out in recent years, according to Professor D. Sotiropoulos (interview about the 7th Congress of Administrative Sciences on the topic "History of Greek Public Administration, 19th-21st Century", 2017). This may also be enhanced by the overall positive attitude of civil servants towards EU contribution to the functioning of public administration and the services provided (Karkatsoulis, 2016).

Law N $N^{\circ} 4336 / 2015$ (Article 3, Par. 5) states that "The authorities intend to modernize and significantly strengthen the Greek administration, and implement in close cooperation with the European Committee, a program for building capacities and depoliticizing the Greek administration" ${ }^{\prime \prime}$. This has brought about changes in the organizational charts of the Ministries, the shaping of a new system of assessment and selection of heads of service, availability, mobility, the reduction of legislative interventions and finally the overall culture of administration and its executives (Manager, 2016).

\section{Conclusions}

If real change is to be effected, our culture must change first (K. Papoulias, 2011)

The culture of public administration is shaped by political interference in the actions of public administration executives, the discrediting of their work, the ineffective way of central services' functioning. Moreover, it is defined by the necessity of designing educational and training programmes that will fully cover the needs of modern public administration, and the necessity of applying the best practices of the private sector to the public sector as well. There should be an enhancement of the spirit of professional culture and public administration executives' adequacy, meritocracy, civil servants' neutrality both as executors of the will of the state and servants of the people beyond all expediency (Pravita, 2018).

According to OECD (2012) there is no evident overall strategic vision for the Greek state, while at the same time there is a pervasive sense of corruption in the public sector, which is linked to politics and opacity typical of the culture of public administration. The Greek government is not joined-up and there is very little coordination, thus

\footnotetext{
${ }^{9}$ Law No 4336/2015 (FEK 94/A/14-8-2015). Pension provisions - Ratification of the draft Convention on financial support/ assistance/aid by the European Stability Mechanism and arrangements for the implementation of the Financing Agreement (in Greek).
} 
compromising reforms that need collective action. There is no sharing of information between ministries. Ministries take decisions which are not reflected in concrete results. Reforms launched in recent years did not bring the expected results, due to poor implementation by the Greek state. There is a production of regulations and administrative acts, while at the same time there is no control and monitoring of their implementation. The current hierarchy is "top heavy" and unreliable, while senior civil servants sometimes are in charge of "ghost" departments with no servants at all. Ministries are affected over time by organizational sprawl, with new departments and units being created to be of service to the servants-supporters of current political authority. There is no systematic record keeping in Greek public sector. The systematic use of data and evidence-based policy-making will constitute "a profound cultural change ${ }^{\prime 10}(O E C D, 2012)$ across Greek public service.

Taking into account the afore-mentioned data, it is concluded that the main characteristics as well as the pathogenies of the culture of public administration are excessive bureaucratization and state interventionism, an obsolete administrative system, the central-government administrative system, a large number of civil servants that do not possess the appropriate knowledge so as to meet the requirements of a modern public administration, mistrust between the state and citizens. Furthermore, noteworthy characteristics are formalism, lack of meritocracy, lack of control and sanctions, inability of creating security conditions for citizens, the large scale of the regulatory competences of the administration, the incomplete monitoring of civil servants' action. It is necessary that an unstable environment and nepotism be avoided in administration (Psychogios, 2009; Makrydemetres, 1999; Chatzisavvas, 1990).

The emerging new culture of public administration is based on the principles of New Public Management (NPM) and the application of the best practices of the private sector to the public sector as well. NPM influences the soft functions of public administration culture and, more specifically, the values, the mentality and the attitudes. It is based on the principles of economy, efficiency, effectiveness, legitimacy and accountability. The training of all public administration executives regardless of their hierarchical level will contribute to the shaping of modern organizational culture. Training programs will contribute to the executives' development, the acquisition of new knowledge and the change of the values and mentality of public administration (Michalopoulos, 2018). The tool of the Common Assessment Framework underlines the significance of organizational culture in public administration and supports that it is influenced by national, social and political traditions and administrative systems, and contributes to the creation of a set of behaviors, moral principles, values.

This new culture of public administration should prevent situations of conflict of interests and clientelist relations, and contribute to the dissemination of codes

${ }^{10}$ OECD (2012). Public Governance Reviews: Greece 2011. Paris: OECD. 
of conduct and good practices to public sector as a whole and be shaped on the basis of a strategic vision entailing a strategic organizational culture directly linked to New Public Management. It should also accept the philosophy of administrative reforms culture, which will enjoy the confidence of all stakeholders, pursue de-bureaucratization, implement the principles of administrative Europeanisation, focus on the improvement of efficiency and effectiveness, highlight the commitment of the employees and place emphasis on the needs of citizens, develop a culture of ethics in public administration through the use and dissemination of best practices. Moreover, it should contribute to the enhancement of public memory, tackle the bureaucratic mentality of employees and formalism, offer opportunities of personal development of employees through their education and training, favor the mobility of employees, which can contribute to the shaping and renewal of the culture of the administrative mechanism, put emphasis on the culture of cooperation, communication, and adapt to the changes of both the internal and external environment (Karkatsoulis, 2014; EKDDA, 2012; Papoulias et al, 2005).

Regarding the concept of organizational culture, there are many definitions that highlight its dynamic character and particular characteristics. Public administration culture has been shaped since the first years of independence and constitutes a mixture of the Weberian model of administration along with the Ottoman administrative origins. This mixture resulted in the shaping of a particular culture mainly characterized by cumbersome administrative structures and excessive bureaucratization. This is the reason why the implementation of new administrative tools, such as NPM, as well as the proposals of OECD, will contribute to the shaping of a new culture adapted to the demands of modern era and society.

The Code of Ethics and Conduct of the Ministry of Finance highlights the significance of organizational culture when it states that "Any action of the civil servants of the Ministry of Finance must be characterized by professional integrity and be in accordance with the highest possible standards of ethics, since the servant contributes to the culture of the Ministry as an organization that primarily provides services to society. The Ministry and its servants are bound by a culture of ethics, according to which, no matter how urgent the assigned work may be, the servant must never jeopardize the quality of the services provided, encourage others to break the law, the present Code or the applicable policies and procedures. The culture of ethics contributes to the fostering of a positive working environment, promotes teamwork and helps create and support a modern and effective public service. Any conduct manifested by act or omission, that deviates from the anticipated one, stands in contrast to the culture of ethics and the applicable legislation; even if this very conduct is not criminally or disciplinary punishable, it is regarded to be contrary to the present Code" (Stamatopoulos, 2013) ${ }^{11}$.

\footnotetext{
${ }^{11}$ Stamatopoulos, G. ( 2013, May 17). Code of Ethics and Conduct of the Ministry of Finance. Forin.gr Retrieved from https:// www.forin.gr/articles/article/8394/kwdikas-hthikhs-deontologias-upourgeiou-oikonomikwn (in Greek).
} 
At the core of the culture of a modern and effective public administration there should be the set of values which executives should necessarily possess in their daily routine. The culture of administration affects both the relations between administration and citizens, as well as the growth of the country. These values should focus on a shared identity and an effective cooperation, satisfy the stakeholders' expectations for cooperation, respect for the individuality and development of public sector executives, the enhancement of public services' good reputation, communication, honesty and finally, the implementation of the principles of ethics and integrity, as well as legitimacy in public administration as a whole.

\section{Bibliography}

1. Broustas, D. (2003). Corporate culture. Hellenic Bank Association Bulletin July-August - September, 173 - 182 (in Greek).

2. Chalikias, M., Manolessou, Al., \& Lalou, P. (2015). Research Methodology and Introduction to statistical data analysis using IBM SPSS Statistics. Athens: Kallipos (in Greek).

3. Chatzisavvas, G. (1990). The (non) bureaucracy. Ideotype and Greek reality. Review of Social Research, 79, 28 - 43 (in Greek).

4. Gavriil, G. (1995). A cultural perspective of organizations. In I. Tsivakou (ed.), Action and system. Modern approaches to the theory of organizations (pp. 185 - 265). Athens: Themelio (in Greek).

5. Gioulos, G., \& Filopoulou, M. (2019). Research of recording the views and perceptions of employees in Public Administration on the digitilisation/ automatization of processes, Koinoniko Polykentro of the Civil Servants' Confederation (ADEDY). Retrieved from https://kpolykentro.gr/wp-content/ uploads/2019/12/20191108_digitalministry_report_press.pdf, (in Greek).

6. Hofstede, G. (1991). Cultures and organizations: Software of the mind. CA: Sage.

7. Hofstede, G. (2011). Dimensionalizing cultures: The Hofstede model in context. Online Readings in Psychology and Culture 2(1).

8. Iordanoglou, Ch. (2012). The "size" of the post-civil war state. Open Seminar of Economic History. Retrieved from http://www.e-history.eu/images/uploads/ Paper\%20-\%202012_01_23.pdf (in Greek).

9. Karkatsoulis, P. (2014). Administrative pathology and administrative reform, Competitiveness for growth: Policy proposals. Athens: Hellenic Bank Association (in Greek). 
10. Karkatsoulis, P. (2016). Research: What do Greeks believe. A Special Analysis- What do civil servants believe. diaNEOsis. Retrieved from https://www.dianeosis.org/2016/02/ti-pistevoun-dimosio/ (in Greek).

11. Kondylis, P. (2007). The decline of urban culture. From modern to post-modern era and from liberalism to mass democracy ( $4^{\text {th }}$ ed.). Athens: Themelio (in Greek).

12. Koulouri, A. (2019). Organizational culture in health services: Characteristics, advantages and disadvantages. Hellenic Journal of Nursing Science, 12(1), 5-12 (in Greek).

13. Ladi, St. (2015). Is it true that the Greek public sector is too big?. ELIAMEP. Retrieved from

https://crisisobs.gr/2015/04/stella-ladi-ine-alithia-oti-o-dimosios-tomeasstin-ellada-ine-ipervolika-megalos/ (in Greek).

14. Law No 4336/2015 (FEK 94/A/14-8-2015). Pension provisions - Ratification of the draft Convention on financial support/assistance/aid by the European Stability Mechanism and arrangements for the implementation of the Financing Agreement (in Greek).

15. Lozga, E., \& Stravakou, P. (2018). The administrative culture in education. The case of Greece. Education Sciences, 1, 53 - 73 (in Greek).

16. Makrydemetres, A. (1999). Administration and society: public administration in Greece. Athens: Themelio (in Greek).

17. Makrydemetres, A., \& Pravita, M. I. (2012). Public administration (5 ${ }^{\text {th }}$ ed.). Athens - Thessaloniki: Sakkoulas S.A. (in Greek).

18. Manager (2016, November-December). The modernization of public administration, a special edition on Public Administration (in Greek).

19. Mandravelis, P. (2011, November 6). The No's and Yes' in Greek history. Sunday's Kathimerini, 27 (in Greek).

20. Manitakis, Ant. (2015). Public administration and administrative reform, prisoners of overregulation and formalism: proposals for their disengagement'. Presentation at a workshop of the National School of Judges. Retrieved from https://www.constitutionalism.gr/manitakis-dioikitiki-metarruthmisi2016/ (in Greek).

21. Martin, J., \& and Siehl, C. (1983). Organizational culture and counterculture: An uneasy symbiosis. Organizational Dynamics, 122, 52 - 65.

22. Michalopoulos, N. (2018). Standards of public administration. Basic concepts- Alternative approaches. Athens: Papazisis (in Greek). 
23. Ministry of Interior and Administrative Reorganization (2013). The Common Assessment Framework. Improving public organizations thorough self-assessment. Athens: National Printing House (in Greek).

24. Mouzelis, N. (2008, November 24). Why do reforms fail?. To Vima. Retrieved from https://www.tovima.gr/2008/11/24/opinions/giati-apotygxanoyn-oimetarrythmiseis/ (in Greek).

25. Musaraj, A., \& Gerxhi, J. (2010). Communication and Ethical Behavior in the Public Service. Academicus International Scientific Journal ISSN, 2079-3715.

26. Musaraj, A. (2011). Communication processes, public administration and performance evaluation. Academicus International Scientific Journal, 2(03), 28-37.

27. National Centre for Public Administration and Local Government (EKDDA) (2012). Conference on ethics in modern public administration. Athens: National Printing House. Retrieved from https://www.ekdd.gr/ekdda/files/news/ Praktika_Ekdda_Ena_GR.pdf (in Greek).

28. OECD (2012). Public Governance Reviews: Greece 2011. Paris: OECD.

29. Papoulias, D., Sotiropoulos, D., \& Oikonomou, Ch. (2005). Administrative culture, reform and politics. The case of the National School of Public Administration. Greek Political Science Review, 26, 87 - 108 (in Greek).

30. Pottakis, Andr. (2019). Ombudsman: The culture of public administration has not changed. AMNA Retrieved from https://www.amna.gr/home/ article/333090/Sunigoros-tou-Politi-And-Pottakis-Einai-megalo-to-stoichimagia-na-to-chasoume (in Greek).

31. Pravita, M. (2018). Reorganization of Staff Councils of Civil Servants. Professionalism versus Politicization. Greek Political Science Review, 44(1), $49-75$ (in Greek).

32. Presidency of the Hellenic Republic (2011). Activities Archive. Retrieved from http://www.presidency.gr/antifonisi-toy-proedroy-tis-dimokratias-k-karoloypapoylia-sto-dimarcho-mesologgioy-kata-to-episimo-geyma-sto-mesologgi/ (in Greek).

33. Prevezanou, K. (2011). The dimension of the actual and the expected in the behavior and attitudes of civil servants from 1995 to 2005. Athens: Papazisis (in Greek).

34. Psychogios, A. (2009). Administrative culture and TQM: Towards a nationally defined Total Quality Framework. In A. Makrydemetres, L. Maroudas, \& M-E Pravita (Eds.), Current Trends in Administrative Science: 'New Public Administration'-Corporate Social Responsibility and Civil Society, 2nd Congress of Administrative Sciences (pp. 81 - 98). Athens- Thessaloniki: Sakkoulas (in Greek). 
35. Saunders, M., Lewis, Ph., \& Thornhill, A. (2014). Research Methods for Business Students. Thessaloniki: Disigma (in Greek).

36. Schein, E. H. (2004). Organizational culture and leadership (3 ${ }^{\text {rd }}$ ed.). San Francisco: Jossey-Bass.

37. Sotiropoulos, D. (2001). The top of clientelist state. Organization, staffing and politicization of the senior levels of central administration in Greece, 1974 - 2000. Athens: Potamos (in Greek).

38. Spanou, K. (2018). Reforms in Public Administration under the crisis: Overview, Description, Evaluation. Athens: ELIAMEP (in Greek).

39. Stamatopoulos, G. ( 2013, May 17). Code of Ethics and Conduct of the Ministry of Finance. Forin.gr Retrieved from https://www.forin.gr/articles/article/8394/ kwdikas-hthikhs-deontologias-upourgeiou-oikonomikwn (in Greek).

40. Trantidis, A. (2016). Clientelism and Economic Policy: Greece and the Crisis. London and NY: Routledge.

41. Tsekos, Th. (2003). Establishment and reproduction of a non-Weberian bureaucracy. The historical evolution of Greek public administration (PhD Thesis). General Department of Law, Panteion University, Athens (in Greek).

42. Tsekos, Th. (2015). Structural changes and administrative reform. In N. Georgarakis \& N. Demertzis (Eds.), The political portrait of Greece. Crisis and the deconstruction of politician (pp. $359-377$ ). Athens; National Center for Social Research: Gutenberg (in Greek).

43. Tsivakou, I. (2013). The bureaucratic darkness. The time of the law. Athens: Sideris (in Greek).

44. Tsoukalas, K. (1986). Employment and employees in the capital: Opacity, questions, answers. Review of Social Research, 60, 3-71 (in Greek).

45. Tsoukalas, K. (1987). State, society, work in post-war Greece ( $2^{\text {nd }}$ ed.). Athens: Themelio (in Greek).

46. Vournas, T. (1998). History of modern Greece. From the Greek war of independence in 1821 till the Goudi coup 1909. Athens: Patakis (in Greek).

47. Zeugaridis, Sp., \& Stamatiadis G. (1997). Human resources management and supervision. Athens: Interbooks (in Greek). 